AgNIESZKA ŻUR

Uniwersytet Ekonomiczny w Krakowie, Polska - Cracow University of Economics, Poland

\title{
Możliwości i ograniczenia przedsiębiorczości w kontekście zwalczania wykluczenia społecznego
}

\section{Contributions and Limitations of Entrepreneurship in Fighting Social Exclusion}

Streszczenie: Artykuł przedstawia przedsiębiorczość jako realną odpowiedź na narastające problemy społeczne, w szczególności lokalne, związane z wykluczeniem społecznym jednostek i grup. Ma charakter eksploracyjno-analityczny i oparty jest na przeglądzie literatury tematu, jak również na analizie istniejących rozwiązań praktycznych na styku przedsiębiorczości społecznej i wykluczenia społecznego. Opracowanie sugeruje, że przedsiębiorczość może być ścieżką wyjścia z zamkniętego obszaru wykluczenia społecznego, jeśli przedsiębiorca podejmie wysiłek działań przedsiębiorczych w tym obszarze. Aby tak się stało, musi on zidentyfikować okazję przedsiębiorczą, która staje się punktem wyjścia do działań przedsiębiorczych w ramach samozatrudnienia, przedsiębiorczości komercyjnej bądź też przedsiębiorczości społecznej. Wykluczenie społeczne może stanowić zatem punkt wyjścia do okazji przedsiębiorczej. Istnieje wysokie prawdopodobieństwo, że jest ukrytym źródłem cennych zasobów ludzkich, kompetencji, talentów i pracy. Wnioski końcowe opracowania prezentują potencjalne ścieżki wyjścia z obszaru wykluczenia społecznego przez przedsiębiorczość oraz przedstawiają przewagę ścieżek opartych na przedsiębiorczości nad rozwiązaniami związanymi z pomocą państwa lub organizacji charytatywnych.

\begin{abstract}
The article is devoted to the contemporary role of entrepreneurship in fighting social exclusion. It presents entrepreneurship as a potential answer to social problems relating to social exclusion. The study has an exploratory and analytical character and is based on an integrated literature review as well as analysis of existing practical solutions on the intersection of social entrepreneurship and social exclusion. The study suggests that entrepreneurship can be an effective path of exiting the area of social exclusions for individuals and groups, through self-employment, commercial or social entrepreneurship. Social exclusion can therefore be the source of entrepreneurial opportunity, holding hidden human and work resources. Conclusions present potential pathways created by entrepreneurial actions enabling social inclusion and the advantages of these over state-led or charity-based solutions.
\end{abstract}

Słowa kluczowe: inkluzja społeczna; przedsiębiorczość; przedsiębiorstwo społeczne; wykluczenie społeczne

Keywords: entrepreneurship; social exclusion social inclusion; social enterprise

Otrzymano: 12 stycznia 2016

Received: 12 January 2016

Zaakceptowano: 26 lutego 2016

Accepted: 26 February 2016 


\section{Sugerowana cytacja/Suggested citation:}

Żur, A. (2016). Możliwości i ograniczenia przedsiębiorczości w kontekście zwalczania wykluczenia społecznego. Przedsiębiorczość - Edukacja, 12, 315-325.

\section{Wstęp}

Przedmiotem niniejszego artykułu jest zjawisko wykluczenia społecznego. Opracowanie podejmuje temat współczesnej roli przedsiębiorczości w zwalczaniu tego niepożądanego zjawiska. Opiera się za założeniu, że istniejące na rynku przedsiębiorstwa wykorzystują narzędzia ekonomiczne do osiągania nie tylko celów ekonomicznych, ale też, w sposób celowy lub niecelowy, do realizacji celów społecznych. Dodatkowo, przekształcają zasoby rynkowe w kapitał społeczny (Stryjan, 2004), co uzasadnia podjęcie próby analizy ich potencjalnej roli w zwalczaniu wykluczenia społecznego.

Wiodącym problemem badawczym niniejszego artykułu jest identyfikacja roli przedsiębiorstw społecznych w zwalczaniu wykluczenia społecznego. Podstawowe pytania badawcze to:

1. Czy przedsiębiorczość może odgrywać istotną rolę w zwalczaniu wykluczenia społecznego?

2. Czy sytuacje wykluczenia społecznego mogą stanowić punkt wyjścia do okazji przedsiębiorczych?

3. Czy przedsiębiorczość społeczna ma przewagę w zwalczaniu wykluczenia społecznego nad rozwiązaniami polityki społecznej państwa i organizacjami charytatywnymi?

Celem naukowym badania jest zatem zidentyfikowanie roli przedsiębiorczości w zwalczaniu wykluczenia społecznego. W ramach tak sformułowanego celu głównego wyodrębniono szereg celów szczegółowych:

1. Identyfikacja kluczowych konceptualizacji wykluczenia społecznego w świetle literatury.

2. Identyfikacja potencjalnych sposobów, którymi przedsiębiorczość przyczynia się do zwalczania wykluczenia społecznego.

3. Konceptualizacja okazji przedsiębiorczych opartych na sytuacjach wykluczenia społecznego określonych grup społecznych.

4. Zaproponowanie modelu inkluzji społecznej w kontekście przedsiębiorczości społecznej.

Artykuł składa się z założeń metodycznych, w których przedstawiono proces badawczy, części teoretycznej oraz wniosków końcowych stanowiących podsumowanie rozważań.

\section{Założenia metodyczne}

Ostatnie dekady przyniosły nową falę dyskusji naukowych w ramach poszukiwania optymalnych modeli zwalczania wykluczenia społecznego. Rosnąca liczba opracowań kwestionuje jednowymiarowy model oparty na interwencji oraz aktywnej polityce państwa i postuluje wielowymiarowe podejście do rozwiązywania problemu wykluczenia społecznego, oparte na współwystępowaniu i komplementarności rozwiązań sektora państwowego, sektora non-profit i sektora for-profit (Skillen et al., 2007). Kluczową rolę w tej nowej fali zajmuje przedsiębiorczość jako czynnik podnoszący skuteczność i efektywność walki z wykluczeniem społecznym.

Teoria przedsiębiorczości koncentruje się na identyfikacji i eksploatacji okazji rynkowych. Poszukuje odpowiedzi na pytania: gdzie, jak i dlaczego w pewnych kontekstach 
społeczno-ekonomicznych okazje rynkowe się pojawiają lub są kreowane, a następnie eksploatowane (Shane, Venkataraman, 2000). Niniejsze opracowanie sytuuje się w nurcie rozważań poświęconych postrzeganiu określonych warunków społecznych lub kondycji społecznej (jak wykluczenie społeczne) jako okazji przedsiębiorczej. Na podstawie dostępnych opracowań krajowych i zagranicznych autorka zmierza do określania roli przedsiębiorczości w zwalczaniu wykluczenia społecznego.

Opracowanie ma charakter eksploracyjno-analityczny i oparte jest na przeglądzie literatury tematu, jak również na analizie istniejących rozwiązań praktycznych na styku przedsiębiorczości społecznej i wykluczenia społecznego. Podstawową metodą badawczą jest krytyczna analiza treści zgromadzonego materiału literaturowego oraz wnioskowanie logiczne.

Przyjęta metodyka badań opiera się na podejściu dedukcyjnym, a więc usystematyzowanym procesie, w trakcie którego etapowa analiza zgromadzonego materiału prowadzi do formułowania wniosków. Zgromadzony materiał składał się ze źródeł literaturowych w postaci monografii i artykułów naukowych, krajowych i zagranicznych z obszaru przedsiębiorczości, socjologii, polityki społecznej, jak również treści pochodzących z opracowań Ministerstwa Pracy i Polityki Społecznej oraz Komisji Europejskiej.

\section{Wykluczenie społeczne}

Zjawisko wykluczenia społecznego jest pojęciem szerokim, wielowymiarowym i niejednoznacznym. Komisja Europejska podkreśla dwa aspekty wykluczenia społecznego: aspekt partycypacji społecznej oraz relatywność zasobów w zależności od miejsca zamieszkania. Definiuje osoby wykluczone społecznie jako takie, których zasoby są tak ograniczone, że wykluczają ich $\mathrm{z}$ akceptowanych na poziomie minimalnym standardów życia obowiązujących w danym kraju członkowskim. Taka konceptualizacja jednoznacznie sugeruje, że wykluczenie społeczne jest kategorią płynną, zależną od geograficznego występowania, poziomu społeczno-gospodarczego kraju i aktualnie występujących norm ekonomicznych i społecznych (Szopa B., Szopa A., 2011).

Różnice w konceptualizacjach, definicjach, jak również w sposobie analizowania przyczyn wykluczenia, można rozciągnąć na osi ograniczonej dwoma konkurencyjnymi podejściami do badania problemów społecznych w socjologii (Eitzen et al., 2012):

1. person-blame approach - podejście, które postrzega jednostkę jako głównego sprawcę swojego losu i analizuje jednostkowe indywidualne powody oraz przesłanki wykluczenia społecznego. Ta grupa definicji ujmuje zjawisko wykluczenia społecznego jako niepodejmowanie zwyczajowej i społecznie akceptowanej drogi życiowej przez jednostki lub wypadanie z tej drogi z przyczyn zależnych i/lub niezależnych od tej jednostki;

2. system-blame approach - podejście, które koncentruje się na badaniu systemowych uwarunkowań wykluczenia społecznego, związanych z równym dostępem do zasobów, systemowym wsparciem dla osób doświadczonych losowo lub nieradzących sobie w życiu.

Przykładem drugiej grupy definicji jest definicja wykluczenia społecznego przyjęta w $\mathrm{Na}$ rodowej Strategii Integracji Społecznej dla Polski następującej treści: „Wykluczenie społeczne to brak lub ograniczenie możliwości uczestnictwa, wpływania i korzystania z podstawowych instytucji publicznych i rynków, które powinny być dostępne dla wszystkich, a w szczególności dla osób ubogich” (Ministerstwo Pracy..., 2003: 22). 
Współistniejące współcześnie definicje wykluczenia społecznego sytuują to zjawisko w czterech podstawowych kontekstach (Szarfenberg, 2006):

1. uczestnictwa w życiu społecznym,

2. dostępu do zasobów, dóbr i instytucji społecznych,

3. ubóstwa i deprywacji potrzeb,

4. praw społecznych i możliwości ich realizacji.

Przyczyny wykluczenia społecznego bywają bardzo złożone i rozpatrywane są zazwyczaj w ujęciu procesowym. Polskie Ministerstwo Pracy i Polityki Społecznej identyfikuje szereg obszarów przyczyniających się do wykluczenia społecznego: „Wykluczenie społeczne dotyczy jakości życia osób, rodzin lub grup ludności, które znalazły się w niekorzystnych warunkach ekonomicznych i/lub społecznych (bieda, ubóstwo materialne, prześladowanie społeczne), gdyz:

- zostają dotknięte niekorzystnymi procesami społecznymi, wynikającymi z masowych i dynamicznych zmian rozwojowych, np. dezindustrializacji, kryzysów, gwałtownego upadku branż czy regionów;

- nie zostały wyposażone w kapitał życiowy umożliwiający im zdobycie normalnej pozycji społecznej, odpowiedniego poziomu kwalifikacji, wejście na rynek pracy lub założenie rodziny, co dodatkowo utrudnia dostosowywanie się do zmieniających się warunków społecznych i ekonomicznych;

- nie mają dostępu do odpowiednich instytucji pozwalających na wyposażenie w kapitał życiowy, jego rozwój i pomnażanie, co wynika z niedorozwoju tych instytucji spowodowanego brakiem priorytetów, brakiem środków publicznych, niską efektywnością funkcjonowania;

- doświadczają przejawów dyskryminacji, zarówno wskutek niedorozwoju właściwego ustawodawstwa, jak i kulturowych uprzedzeń oraz stereotypów;

- mają cechy utrudniające im korzystanie z powszechnych zasobów społecznych ze względu na zaistnienie niesprawności, uzależnienia, długotrwałej choroby albo innych cech indywidualnych;

- są przedmiotem niszczącego działania innych osób, np. przemocy, szantażu, indoktrynacji” (Ministerstwo Pracy..., 2003: 21).

Zawarte w dokumencie polskiego ministerstwa przyczyny wykluczenia zawodowego nakreślają szerokie spectrum problemów społecznych, które dotykają jednostki i grupy objęte wykluczeniem społecznym. Dodatkowo należy zauważyć współzależność wielu problemów; poszczególne wymiary wykluczenia społecznego często nakładają się na siebie, pogłębiając marginalizację.

Zatem można powiedzieć, że wykluczenie społeczne wiąże się nieodzownie z rozmaitymi deficytami jednostki, rodziny lub grupy, które obniżają poziom życia poniżej akceptowalnego społecznie minimum.

\section{Walka z wykluczeniem społecznym i inkluzja społeczna}

Mając powyższe rozważania na uwadze, można przyjąć, że inkluzja społeczna jest procesem odwrotnym do wykluczenia społecznego i polega na zapewnieniu takiego dostępu do zasobów materialnych, finansowych, społecznych kulturowych, który gwarantuje poziom życia zgodny z poziomem minimalnych standardów obowiązujących w danym kraju, jak również dostęp do instytucji społecznych i rynków. Przeciwdziałanie i walka z wykluczeniem społecznym 
tradycyjnie utożsamiane są z aktywną polityką społeczną państwa, w drugiej kolejności - z organizacjami pozarządowymi, i w trzeciej kolejności - z podmiotami gospodarczymi (Dess, 2007).

Bezsprzecznie państwo ma najszerzej rozwinięty aparat przeciwdziałania wykluczeniu społecznemu i jego zwalczania $\mathrm{z}$ racji gospodarowania znacznymi zasobami przeznaczonymi do tych celów, systemem organizacyjnym obejmującym teren całego kraju oraz aparatem ludzi obsługujących i wdrażających politykę państwa w tym zakresie. Istnieją jednak rozległe obszary życia społecznego, gdzie państwu nie udaje się wprowadzić trwałych zmian. Do tych obszarów należy wykluczenie społeczne. Najczęściej wymieniane powody nieudolności państwa w programach społecznych to: rozbudowana biurokracja, wpływy polityczne i kreowanie zależności (a czasem nawet roszczeniowości) zamiast zaradności (Dess, 2007). Rozwiązania odgórne są z natury oparte na rozbudowanych strukturach i obciążone biurokracją, co nie sprzyja kreatywności i wdrażaniu innowacji. Ponadto programy rządowe nie wykazują wrażliwości na specyfikę lokalnych warunków, problemów i zasobów. Polityki państwowe funkcjonują w sztywnych ramach programów i budżetów rządowych, często pod wpływem nacisków politycznych. Po dekadach eksperymentowania $\mathrm{z}$ różnymi formami rządzenia i interwencji społecznej, wiemy już, że państwo posiada mechanizmy skuteczne dla określonych interwencji społecznych, ale nie dla wszystkich. W konsekwencji państwo często występuje współcześnie w roli nieudolnego świadczyciela pomocy społecznej, a nie agenta pożądanych zmian społecznych.

Rolę państwa w ograniczaniu wykluczenia społecznego uzupełniają organizacje charytatywne i pozarządowe. Część z nich ma charakter filantropijny i ogranicza się do świadczenia pomocy potrzebującym. Częstą ich słabością jest kreowanie zależności, gdyż organizacje charytatywne z założenia mają nieść ulgę i pomoc, a nie inicjować trwałe zmiany społeczne. Ponadto większość tych organizacji dysponuje bardzo ograniczonymi środkami, a możliwość działalności zarobkowej jest w ich przypadku znacznie ograniczona.

Zatem zarówno polityka państwa, jak i działalność organizacji charytatywnych posiada istotne ograniczenia w przeciwdziałaniu i zwalczaniu wykluczenia społecznego.

\section{Rola przedsiębiorczości w zwalczaniu wykluczenia społecznego}

Ostatnie dekady przyniosły gwałtowny rozwój teorii przedsiębiorczości, rozszerzający zakres tego zjawiska poza sferę komercyjną. Przedsiębiorczość utożsamiana jest dzisiaj przede wszystkim z identyfikacją i eksploatacją okazji przedsiębiorczych (Shane, Venkataraman, 2010). Inna popularna definicja określa przedsiębiorczość jako proces rozciągania możliwości poza granice posiadanych zasobów w celu generowania korzyści (Stevenson, Jarillo-Mossi, 1986). Tak szerokie ujęcie tego zjawiska pozwala poszukiwać procesów przedsiębiorczych i owoców tych procesów w sferze nie tylko gospodarczej, ale też społecznej czy też kulturalnej. Przedsiębiorczość jako pewien szczególny rodzaj aktywności ludzkiej generuje korzyści na wielu polach i przyczynia się do szeroko pojętego rozwoju społeczno-gospodarczego krajów (Austin et al., 2006). Kontekst podejmowanych działań może się zmieniać, jednak sedno, czyli mobilizacja zasobów i eksploatacja okazji przedsiębiorczych oraz generowanie korzyści pozostają niezmienne.

Należy zatem przyjrzeć się potencjalnym korzyściom, które niesie przedsiębiorczość pojmowana jako aktywność ludzka zorientowana na cel, charakteryzująca się proaktywnością, innowacyjnością i podejmowaniem skalkulowanego ryzyka (Miller, 1983) dla sfery wykluczenia społecznego. Komisja Europejska przyjęła przedsiębiorczość za podstawowy element swojej 
polityki społecznej: „Przedsiębiorczość jest również napędem rozwoju osobistego i może przyczyniać się do stanu społecznej harmonii, kiedy możliwość prowadzenia swojej działalności gospodarczej jest osiągalna dla każdego, niezależnie od pochodzenia i lokalizacji” (European Commision Entrepreneurship Action Plan, 2004: 3).

Zatem pierwszym i podstawowym sposobem, w jaki przedsiębiorczość przyczynia się do walki z wykluczeniem społecznym, jest możliwość założenia i prowadzenia własnej działalności gospodarczej. Dla wielu osób wykluczonych społecznie z uwagi na swoje pochodzenie, niepełnosprawność lub miejsce zamieszkania, możliwość samozatrudnienia jest sposobem na aktywny udział w życiu społeczno-gospodarczym, niezależność finansową i rozwój. Należy pamiętać, że samozatrudnienie i stanie się przedsiębiorcą to droga dostępna tylko dla wybranych osób objętych wykluczeniem społecznym. Osoby bezdomne, trwale bezrobotne, upośledzone umysłowo najczęściej nie mają dostępu nawet do minimalnych zasobów finansowych, informacyjnych i społecznych, aby udźwignąć to wyzwanie.

W drugiej kolejności należy przyjrzeć się, co inni przedsiębiorcy mogą zrobić dla osób wykluczonych społecznie. Jak przedsiębiorczość innych może przyczyniać się do inkluzji społecznej? Bezpośrednią formą walki z wykluczeniem społecznym jest generowanie miejsc pracy. W przypadku przedsiębiorczości komercyjnej ten potencjał sprowadza się w pierwszej kolejności do generowania miejsc pracy, co należy uznać za bezpośredni i najbardziej pożądany sposób walki z wykluczeniem społecznym. Konsekwentnie od Strategii lizbońskiej to właśnie zatrudnienie i możliwość pracy zarobkowej uznana jest za najskuteczniejszy sposób walki z wykluczeniem społecznym i powrotu do pełnego życia społecznego (inkluzji społecznej) (Dieckhoff, Gallie, 2007), gdyż opiera się na aktywności, sprawczości i samostanowieniu osób niegdyś wykluczonych społecznie z powodu bezrobocia. Nowa Strategia lizbońska (2005) wiele uwagi poświęca zatrudnieniu jako podstawowej formie aktywizacji osób wykluczonych społecznie i podkreśla rolę nie tylko kreacji nowych miejsc pracy, lecz także kreacji lepszych miejsc pracy, czyli trwałych, bezpiecznych, dających możliwość zdobywania cennych kompetencji i możliwość awansu zawodowego oraz społecznego.

Należy również zwrócić uwagę na pośrednią rolę przedsiębiorczości komercyjnej w przeciwdziałaniu wykluczeniu społecznemu. Polega ona na dbaniu o rozwój zawodowy, osobisty i społeczny osób zatrudnionych. Praca jest miejscem, gdzie człowiek ma możliwość rozwijania kompetencji zawodowych, nawiązywania relacji społecznych i realizacji siebie. Ponadto małe i średnie przedsiębiorstwa są filarem lokalnych społeczeństw, powiązane licznymi zależnościami i relacjami z siecią lokalnych dostawców, producentów, odbiorców, konsumentów i instytucji. Przyczyniają się one do budowania żywej tkanki społecznej. Pośrednia rola przedsiębiorczości komercyjnej odnosi się również do aktywnych działań na rzecz społeczności lokalnej w ramach społecznej odpowiedzialności biznesu. Z uwagi na swoją nieanonimowość, wplątanie w sieć lokalnych relacji, małe i średnie przedsiębiorstwa przyjmują nieraz bardzo aktywną funkcję we wspieraniu rozwoju społecznego: pośrednio w partnerstwie z lokalnymi organizacjami społecznymi lub bezpośrednio przez wsparcie dla lokalnych domów dziecka, organizację imprez lub prowadzenie fundacji, programów poświęconych konkretnemu problemowi społecznemu.

W toku identyfikacji potencjału przedsiębiorczości w walce $\mathrm{z}$ wykluczeniem społecznym nie można pominąć przedsiębiorstw społecznych, czyli przedsiębiorstw założonych i prowadzonych w celu realizacji celów społecznych. Taka formuła działania zalicza je do grupy przedsiębiorstw społecznych. W Polsce są to liczne spółdzielnie i mniej liczne podmioty prawa handlowego jak dzielność osób fizycznych czy też spółka z ograniczoną odpowiedzialnością, 
prowadzone w celach społecznych (w języku potocznym: non-profit). Polskie prawo przewiduje prowadzenie spółki z o.o. w celach społecznych. W takich przedsiębiorstwach gospodarowanie zyskiem ogranicza się do reinwestowania w cel spółki i nie podlega podziałowi między udziałowców. Prowadzenie działalności społecznej w formie prawnej tradycyjnie zarezerwowanej dla przedsiębiorców komercyjnych ma swoje zalety, gdyż pozostawia przedsiębiorcy najszersze pole niezależności decyzyjnej i finansowej, co przekłada się na elastyczność i dynamiczność takich przedsiębiorstw. Przedsiębiorstwem społecznym nazywa się organizację, której przedmiotem działania są innowacyjne przedsięwzięcia podejmowane na zasadach rynkowych w ramach lub na styku sektora prywatnego, publicznego i/lub sektora non-profit w celu generowania korzyści społecznych (Austin et al., 2006). Taka definicja przedsiębiorczości społecznej zakłada niezależność samego przedsiębiorcy lub grupy przedsiębiorców i swobodę ich działania w ramach wolego rynku oraz oparcie działalności na innowacyjnym pomyśle.

Przedsiębiorstwa społeczne w sposób bezpośredni mogą przyczyniać się do walki z wykluczeniem społecznym lub przeciwdziałania temu zjawisku. $Z$ definicji realizują cel społeczny, który może polegać na wyprowadzaniu ludzi z bezdomności, nałogów, bezrobocia przez zatrudnienie, aktywizację, cykle szkoleń, formy aktywności i zaangażowania społecznego. Przedsiębiorstwa społeczne polegają często na pracy wolontariuszy, budują relacje z rozmaitymi organizacjami i instytucjami, tak aby realizować ambitne cele społeczne i generować społeczną wartość dodaną.

Podsumowując, przedsiębiorczość może przyczyniać się do walki z wykluczeniem społecznym po pierwsze przez kreowanie przestrzeni do samozatrudnienia, a po drugie - przez działania przedsiębiorców komercyjnych i społecznych.

\section{Wykluczenie społeczne jako okazja przedsiębiorcza}

Okazja jest centralną nicią przewodnią w teorii przedsiębiorczości. Należy zatem postawić pytanie: czy sytuacja wykluczenia społecznego może być punktem wyjścia okazji przedsiębiorczej?

Jak zostało wspomniane na wstępie, sytuacje wykluczenia społecznego charakteryzują się przede wszystkim ubóstwem materialnym (bezrobocie, bezdomność) bądź prześladowaniem społecznym (dyskryminacja, stereotypizacja). Obydwa przypadki kreują często bezradność ludzi i niemożność samodzielnego wyjścia z zaistniałego stanu. Ludzie bez perspektyw i możliwości samodzielnego działania na rzecz poprawienia swojego losu nierzadko są bardzo mocno zmotywowani do podjęcia działań i zmiany swojej sytuacji. Wysoki poziom motywacji może stanowić ten rzadki zasób, o który pracodawcy zabiegają na rynku pracy. Dodatkowo, ludzie wykluczeni społecznie mogą posiadać cenne kompetencje, zdobyte na wcześniejszych etapach swojego życia bądź nabyte w trakcie bezdomności lub bezrobocia, kiedy o każdy zasób życiowy musieli walczyć (Hall et al., 2012). Przedsiębiorcy, którzy zidentyfikują ten stan rzeczy jako okazję przedsiębiorczą, będą poszukiwać ludzi do pracy i do współpracy.

Podobnie przedstawia się sytuacja ludzi prześladowanych lub dyskryminowanych. Taka sytuacja stawia ich w słabej pozycji przetargowej na rynku pracy. Niemożność znalezienia zatrudnienia może okazać się powodem bardzo dużej motywacji, oddania i ponadprzeciętnej rzetelności w pracy w sytuacji zatrudnienia przez przedsiębiorcę. 
Rosnąca liczba autorów zwraca uwagę na ukryte zasoby w obszarze wykluczenia społecznego i na dole piramidy społecznej. Okazje przedsiębiorcze mogą w tym obszarze dotyczyć zasobów ludzkich, kapitału społecznego i siły roboczej, ale również potencjalnych konsumentów. C. Prahalad (2007) zwraca uwagę na nasycenie rynków w krajach wysoko rozwiniętych i na okazje przedsiębiorcze ukryte w dolnych obszarach piramidy społecznej, gdzie zasoby są skromne, ale za to potrzeby są wielkie. Autor przywołuje szereg przykładów innowacyjnych produktów i usług skierowanych do odbiorców objętych wykluczeniem społecznym, które przyczyniają się do walki z tym zjawiskiem. Ich konsumenci nie raz uzyskują dofinansowanie z programów rządowych lub organizacji non-profit na pokrycie kosztów zakupu.

Wykluczenie społeczne może stanowić zatem punkt wyjścia do okazji przedsiębiorczej. Istnieje wysokie prawdopodobieństwo, że jest ukrytym źródłem cennych zasobów ludzkich, kompetencji, talentów i pracy. Ponadto obszary wykluczenia społecznego mogą stać się rynkiem zbytu bardzo specyficznych produktów i usług przeznaczonych dla ludzi o niezaspokojonych potrzebach elementarnych. Przedsiębiorczość w obszarze wykluczenia społecznego wymaga jednak wrażliwości społecznej, wyobraźni, dokładnego rozpoznania i zdiagnozowania rynku oraz innowacyjności (Konda et al., 2015).

\section{Wnioski}

Wnioski z niniejszego opracowania zostały przedstawione na rycinie 1. Przedsiębiorczość może być ścieżką wyjścia z zamkniętego obszaru wykluczenia społecznego, jeśli przedsiębiorca podejmie wysiłek działań przedsiębiorczych w tym obszarze. Aby tak się stało, musi on zidentyfikować okazję przedsiębiorczą, która staje się punktem wyjścia do działań przedsiębiorczych w ramach samozatrudnienia, przedsiębiorczości komercyjnej bądź też przedsiębiorczości społecznej. Inkluzja społeczna następuje w wyniku wyjścia człowieka z obszaru wykluczenia społecznego przez: podjęcie działalności gospodarczej, podjęcie pracy u przedsiębiorcy, wykorzystanie oferty szkoleń i programów aktywizacji prowadzonych przez przedsiębiorców społecznych, ofert produktów i usług przeznaczonych dla tej grupy społecznej, rozwój swoich kompetencji zawodowych i/lub kompetencji społecznych.

Przedsiębiorczość otwiera zatem potencjalnie szerokie pole do zwalczania wykluczenia społecznego i - co więcej - daje szereg wyjątkowych korzyści i przewag nad rozwiązaniami centralnymi. Wprowadzenie na scenę przemian społecznych prywatnej inicjatywy i przedsiębiorczości otwiera nowe ścieżki rozwoju i niesie ze sobą szereg potencjalnych korzyści. Pierwsza istotna kontrybucja to innowacje. Teoria rozwoju gospodarczego Schumpetera (1960) stawia przedsiębiorców w centrum zainteresowania jako tych, którzy wprowadzają nowe kombinacje zasobów i nowe rozwiązania. Przypisał on przedsiębiorcy rolę burzyciela równowagi rynkowej i innowatora, który w poszukiwaniu zysku w nowy sposób łączy czynniki produkcji. Według tego autora główną siłą sprawczą rozwoju gospodarczego są przedsiębiorcy (nie administratorzy) obdarzeni duchem kreatywnej destrukcji. Burzą to, co przestarzałe i nieefektywne, a uruchamiają to, co twórcze i nowe. Przedsiębiorczość niesie zatem obietnicę postępu w sferze społecznej i walki z wykluczeniem społecznym.

Po drugie, przedsiębiorczość społeczna opiera się na ekonomicznym rachunku i efektywnym działaniu. To stanowi zarówno o kontrybucji, jak i ograniczeniu społecznego wymiaru przedsiębiorczości. Przedsiębiorca działa na własne ryzyko i odpowiedzialność, w ramach zasad rynkowych i każde jego przedsięwzięcie podlega naturalnej weryfikacji rynkowej. 
Ryc. 1. Inkluzja społeczna przez przedsiębiorczość

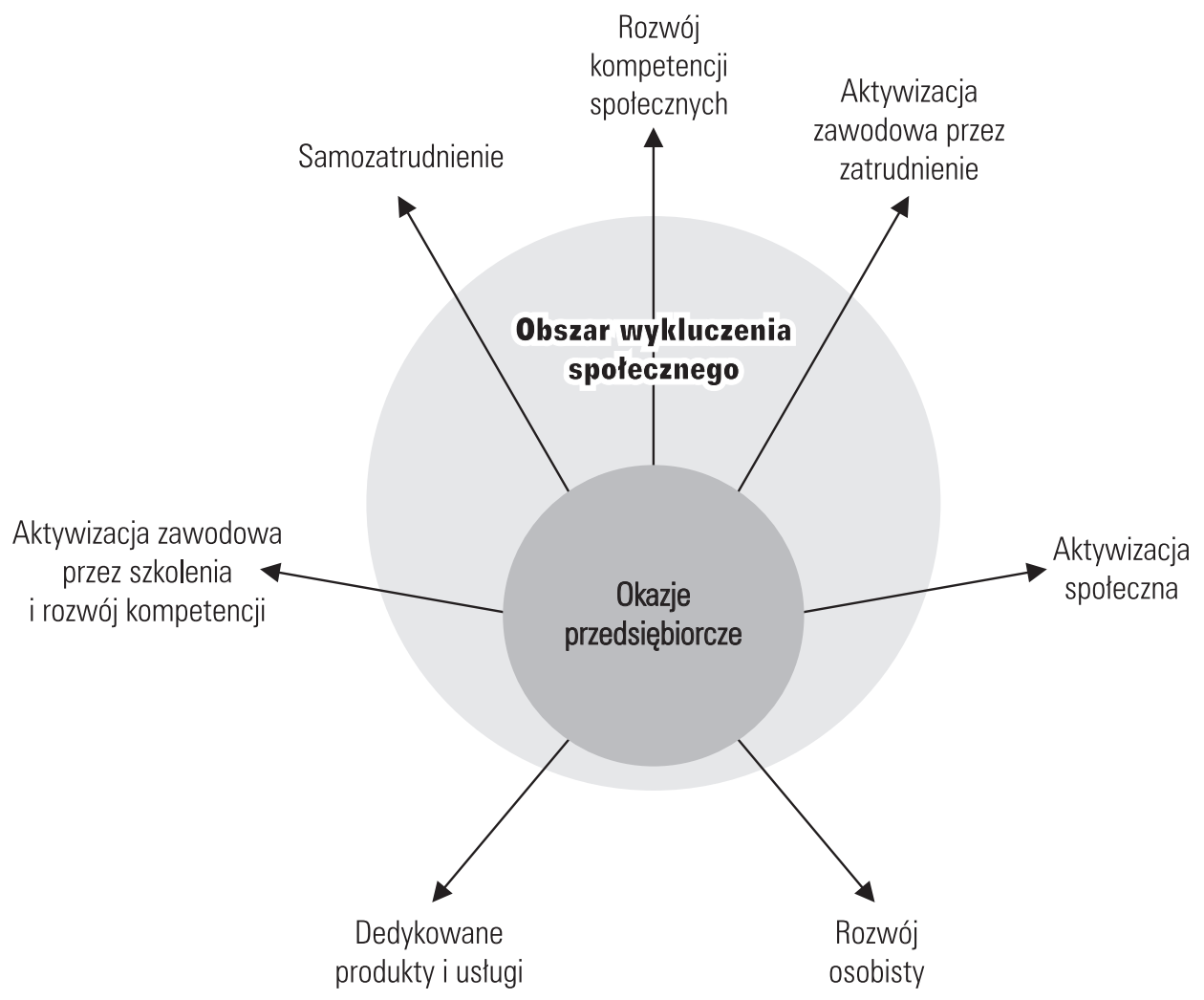

Źródło: opracowanie własne

Proces naturalnej selekcji generowany przez prawa rynku jest najlepszym jak do tej pory mechanizmem weryfikacyjnym przedsięwzięć. Skuteczne, potrzebne i rynkowe rozwiązania przetrwają i będą się rozwijały, a słabsze zostaną wyeliminowane. Aktywność przedsiębiorców społecznych w sferze socjalnej na warunkach rynkowych umożliwia społeczeństwu eksperymentowanie, testowanie nowych rozwiązań oraz uczenie się nowego działania przy zdecydowanie niższym ryzyku dla sfery budżetowej. Nie można tego powiedzieć o programach rządowych, które zabudżetowane są na określany czas z góry i prowadzone niezależnie od swojej skuteczności.

Autonomia przedsiębiorców i działanie w ramach wolego rynku oznaczają, że posiadają oni swobodę mobilizowania zasobów, zarówno finansowych, jak i ludzkich. Tej możliwości nie mają organizacje pozarządowe działające w Polsce najczęściej w formie stowarzyszeń, spółdzielni i fundacji. Przedsiębiorcy mają swobodę korzystania z różnych źródeł finansowania oraz współpracy z rozmaitymi podmiotami. Ponadto przedsiębiorcy, działając niezależnie od struktur rządowych na własne ryzyko i odpowiedzialność, posiadają większą możliwość mobilizowania innych zasobów, w tym ludzkich, szybkiego reagowania na zmiany, dostrajania się do potrzeb rynku i potrzeb społecznych. Tak rozumiana elastyczność podnosi ich efektywność. 
Przedsiębiorczość, zarówno komercyjna, jak i społeczna, jest zatem obiecującym kierunkiem rozwoju w kontekście zwalczania wykluczenia społecznego, gdyż opiera się na przeobrażaniu problemów w okazje przedsiębiorcze, a jej rozwiązania nie generują postaw roszczeniowych, a raczej postawy aktywne i poczucie sprawczości i odpowiedzialności. Prezentuje wyraźne korzyści dla społeczeństwa, gdyż stawia sobie za cel zmiany na lepsze w sferze społecznej, niesie ze sobą innowacje i postęp, wykorzystuje szanse niedostrzegalne dla innych oraz podlega weryfikacji rynkowej. Przyszłe kierunki badań powinny weryfikować te założenia i analizować efekty działalności przedsiębiorczej w sferze wykluczenia społecznego, zarówno pod względem jakościowym, jak i ilościowym.

\section{Literatura}

References

Austin, J., Stevenson, H. i Wei-Skillern J. (2006). Social and commercial entrepreneurship: same, different, or both?. Entrepreneurship theory and practice, 30(1), 1-22.

Blackburn, R. i Ram, M. (2006). Fix or fixation? The contributions and limitations of entrepreneurship and small firms to combating social exclusion. Entrepreneurship and Regional Development, 18(1), 73-89.

Casson, M. (1982). The entrepreneur: An economic theory. Rowman \& Littlefield.

Dess, J.G. (2007). Taking Social Entrepreneurship seriously, Society, 44(3), 24-33.

Dieckhoff, M., Gallie, D. (2007). The renewed Lisbon Strategy and social exclusion policy. Industrial Relations Journal, 38(6), 480-502.

Drucker, P.F. (1985). Entrepreneurial strategies. California Management Review (pre-1986), 27(000002).

Eitzen, D. S., Zinn, M.B., Eitzen Smith, K. (2012). Social problems, Allyn\&Bacon.

Eckhardt, J.T., Shane, S. (2003). Opportunities and entrepreneurship. Journal of management, 29(3), 333-349.

European Commission Entrepreneurship Action Plan (2004). Brussels: Commission of the European Communities.

Hall, J., Matos, S., Sheehan, L., Silvestre, B. (2012). Entrepreneurship and Innovation at the base of the pyramid: a recipe for inclusive growth or social exclusion?. Journal of Management Studies, 49(4), 786-812.

Konda, I., Starc, J., Rodica, B. (2015). Social challenges are opportunities for sustainable development: tracing impacts of social entrepreneurship through innovations and value creation. Ekonomske Teme, 53(2), 215-233.

Miller, D. (1983). The correlates of entrepreneurship in three types of firms. Management science, 29(7), 770-791.

Ministerstwo Pracy i Polityki Społecznej. (2003). Narodowa Strategia Integracji Społecznej dla Polski, Warszawa.

Ministerstwo Pracy i Polityki Społecznej (2013). Krajowy Program Przeciwdziałaniu Ubóstwu $i$ Wykluczeniu Społecznemu 2020. Nowy Wymiar Aktywnej Integracji, Warszawa.

Prahalad, C. (2007). The fortune at the bottom of the pyramid: eradicating poverty through profits, Upper Saddle River, New York.

Schumpeter, J.A. (1960). Teoria rozwoju gospodarczego, Warszawa: PWN.

Shane, S., Venkataraman, S. (2000). The promise of entrepreneurship as a field of research, Academy of management review, 25(1), 217-226.

Skillen, J., Austin, J., Stevenson, H. (2007). Entrepreneurship in the social sector, Sage Publications.

Stevenson, H., Jarrillo-Mossi. J.C. (1986). Preserving entrepreneurship as companies grow. Journal of Business Strategy, 7(1), 10-23. 
Stevenson, H. i. Jarillo, J.C. (1990). A paradigm of entrepreneurship: Entrepreneurial management. Strategic management journal, 11(5), 17-27.

Stryjan, J. (2004). The Practice of Social Entrepreneurship. W: J. Tragalski (red.) Entrepreneurship, Employment and Beyond, Kraków: Wydawnictwo Uniwersytetu Akademicznego w Krakowie.

Szarfenberg, R. (2006). Marginalizacja i wykluczenie społeczne. Warszawa: Instytut Polityki Społecznej. Szopa, B., Szopa, A. (2011). Wykluczenie finansowe a wykluczenie społeczne. Zeszyty Naukowe, 11, Uniwersytet Ekonomiczny w Krakowie.

Agnieszka Żur, doktor nauk ekonomicznych w zakresie nauk o zarządzaniu, absolwentka, a następnie pracownik Uniwersytetu Ekonomicznego w Krakowie. Autorka publikacji z zakresu przedsiębiorczości organizacyjnej oraz przedsiębiorczości społecznej. Zainteresowania badawcze: przedsiębiorczość społeczna, metodyka nauczania. Wieloletnie doświadczenie w nauczaniu przedsiębiorczości i zarządzania. Certyfikowany trener oraz tutor akademicki (w systemie OxCam). Specjalista w zakresie aktywnych metod nauczania na uczelniach wyższych. Członek Academy of Management od 2010 r. Gościnne wykłady m.in. dla Grand Valley State University (Grand Rapids, USA), Western Michigan University (Kalamazoo, USA), Durham University i Luton University (Wielka Brytania), Sodertorn University (Sztokholm, Szwecja).

Agnieszka Żur, PhD in Management (corporate entrepreneurship). A graduate and later employee of the Cracow University of Economics. The author of publications on corporate entrepreneurship and social entrepreneurship. Current research areas include: social entrepreneurship, teaching methodology, socially engaged teaching and learning. Extensive experience in entrepreneurship and management teaching. The certified trainer and academic OxCam tutor. The member of Academy of Management since 2010. A guest lecturer for Grand Valley State University (Grand Rapids, USA), Western Michigan University (Kalamazoo, USA), Durham University and Luton University (Great Britain), Sodertorn University (Stockholm, Sweden).

\section{Adres/Address:}

Uniwersytet Ekonomiczny w Krakowie

Katedra Przedsiębiorczości i Innowacji

ul. Rakowicka 27

31-510 Kraków, Polska

e-mail: zura@uek.krakow.pl

Artykuł powstał w ramach projektu badawczego nr 054/WE-KPI/02/2015/S/5054 pt. „Przedsiębiorczość inkluzywna: współczesne wyzwania i perspektywy rozwoju” sfinansowanego ze środków przyznanych Wydziałowi Ekonomii i Stosunków Międzynarodowych Uniwersytetu Ekonomicznego w Krakowie, w ramach dotacji na utrzymanie potencjału badawczego. 